\title{
贵州龙宫水系坡立谷湖群水文 地貌结构与功能特征
}

\author{
谭明梁虹 \\ （南京大学大地海洋科学系, 南京 210093）（贵州师范大学地理系, 兵回 550001）
}

提要龙官是费州苦名的喀斯特风景点。该区在第四纪构造运动中由于地貌回春,形态逆

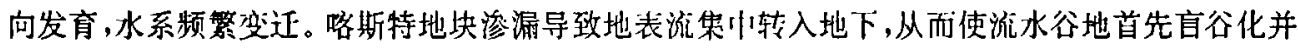
逐步形成注地。在这个过保中，流域地貌复杂响应基面变化，发育了龙宫坡立谷。这些坡立谷的形 成与流域形态演化相联系而不同于 I. Gams 对划分的类型。它们在水系结构小与池下管道相串

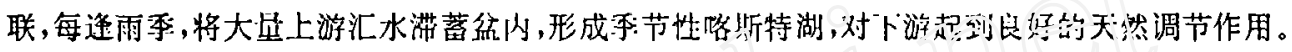

关键词龙宫水系 坡立谷 咯斯特湖每杂响应 水文地貌部

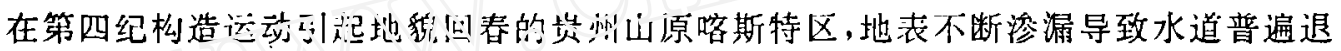

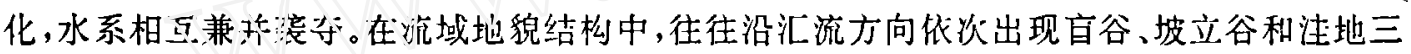
种负地貌类型行规律的组合。这些坡立谷符合 I.Gams 对坡立谷形态的定义, 即具有封闭的 盆形和过境河, 平坦的底部为冲积物所覆盖 [1]。但它们与 I. Gams 所总结的几种坡立谷类 型 ${ }^{[2]}$ 不同, 是流域地貌逆向演化向源推进, 流水谷地注地化的产物 ${ }^{[3]}$ 。由于这些坡立谷处于 流域地表水通道向地下水通道突变的形态发育跃迁部位, 其地下通道的规模往往还不能使 水流顺畅地排泄, 从湎产生 “天然水坝效应”[4], 将流域汇水滞蓄于坡立谷中数日到数月, 形 成季节性喀斯特湖。本文以龙宫水系坡立谷湖群为例, 用喀斯特水文地貌学观点 ${ }^{[5]}$ 分析这类 坡立谷在流域水系演变中的结构成因及其作为天然库群的水文调蓄作用, 即它们的水文地 貌功能。

\section{1 流 域 概 况}

龙官 (旧名龙罩) 位于贯州安顺市西南面, 为龙宫地下河系的总出口。龙宫水洞及其附近 区域是著名的喀斯特风景旅游区。龙宫地下河流域面积约 $250 \mathrm{~km}^{2}$, 属珠江流域。水系大部分 源于安顺溶原分水岭, 自北向南汇入南盘江支流王二河。流域内水系展布主要受 NE 向构造 控制, 而第四纪构造运动的影响使水系于地表和地下相互兼并袭等频繁变迁 (图 1)。在温喛

- 实州省教委白然科学基金项目。

收稳日期: 1993 年 6 月 11 日, 接受日期: 1994 年 1 月 10 日。

作者简介: 濖明, 男, 1954 年生: 1994 年毕业于南京大学大地海洋科学系,获博士学位。现为忯国科学院地质研究

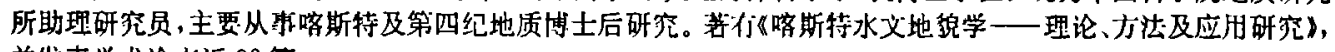
并发表学术论文近 20 篇。 


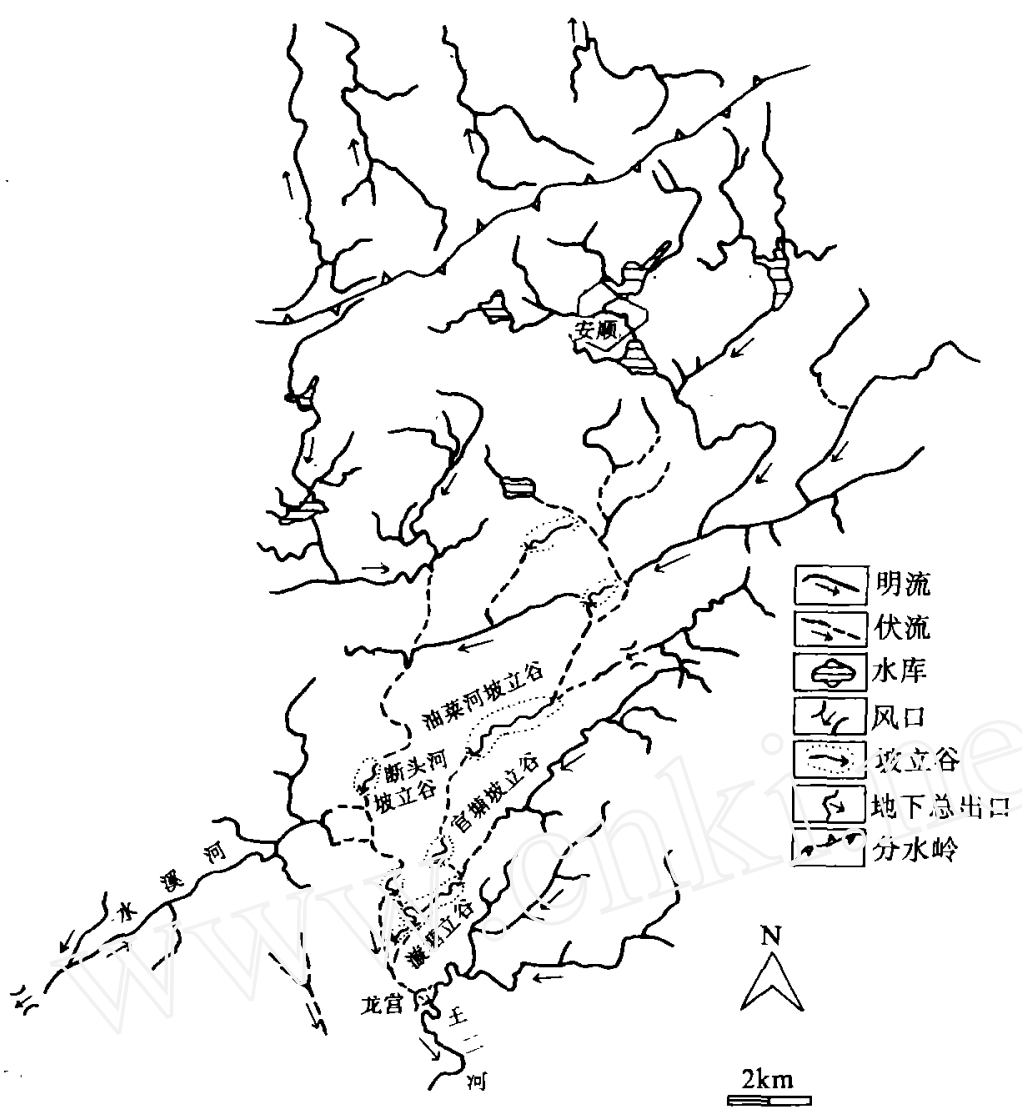

图 1 龙官水系图

Fig. 1 Longgong river system

湿润的气候动力条件下易溶的碳酸盐岩基础上，从分水岭到排泄基准（王二河）发育了一套 类型齐全的峰林溶原、峰丛流水谷地、峰丛坡立谷和峰丛洼地等喀斯特流域组合形态。

\section{2 水系变迁大势}

龙官地下河系虽然其总的走向格局受控于燕山运动形成的 NE 向老构造, 具有构造水 系的基本特征，但由于最近地质吋期云贵高原的隆起以及珠江流域自北面南,由西向东掀斜 抬升, 致使次一级较小流域相继回春, 龙官地下河流域即为其中之一。由于喀斯特作用, 地表 流不断转人地下, 流水谷地退化为干谷进面由于集中渗漏成为注地, 从面打破了原有的水系 格局。主要表现为:

（1）原来的 NE $\rightarrow S W$ 向厸造水系沿最近活动的 NW 向和 NNE 向构造 ${ }^{[6]}$ 向地下发育。 如该水系在淡塘以下水流啃道一条 NW $\left(310^{\circ}\right)$ 断裂发育形成龙宫水洞, 并在相变线处出露, 就近排入深切的王二河。

（2）由于较近的新排泄基准所传递的回春信息能更快地到达水系各点,使水系上游对 新基准响应调整。如水溪河即由原来的 SW 流向转为现在的 NE 流向成为“倒淌河”。 
（3）由于龙宫水系总出口的形成,使原来统一的 $\mathrm{NE} \rightarrow \mathrm{SW}$ 向构造水网被割裂。从图 1 可见,龙宫水系西南面有另一地下测系, 其排泄基准也是王二汕。在用水文地貌学方法所作 的流域最低势面中 (以 $1 \mathrm{~km}^{2}$ 为面积单位的流域地形网格中最小高程等值线集合), 发现龙 宫水系北部较平缓区地下分水线不封闭，流域有一定的开放性(图 2)。而南面的地下河系从 地下不断㴊源袭夺, 已经将地下分水界向北推进到它宫地表流域以内（图 2 中地表分水线以 北为龙宫地表流域)。

由于近期的水系变迁,流域重新调整,水流与形态所表现的“不称”形成扩展坡立谷湖盆 的动力源。但另一方面, 注地向心水系的发育义限制了湖盆进一步的扩大。因此, 这种流水 喀斯特类型的坡立谷 ${ }^{[4]}$ 实际是地貌发育对基面变化复杂响应 ${ }^{[7]}$ 的结果。

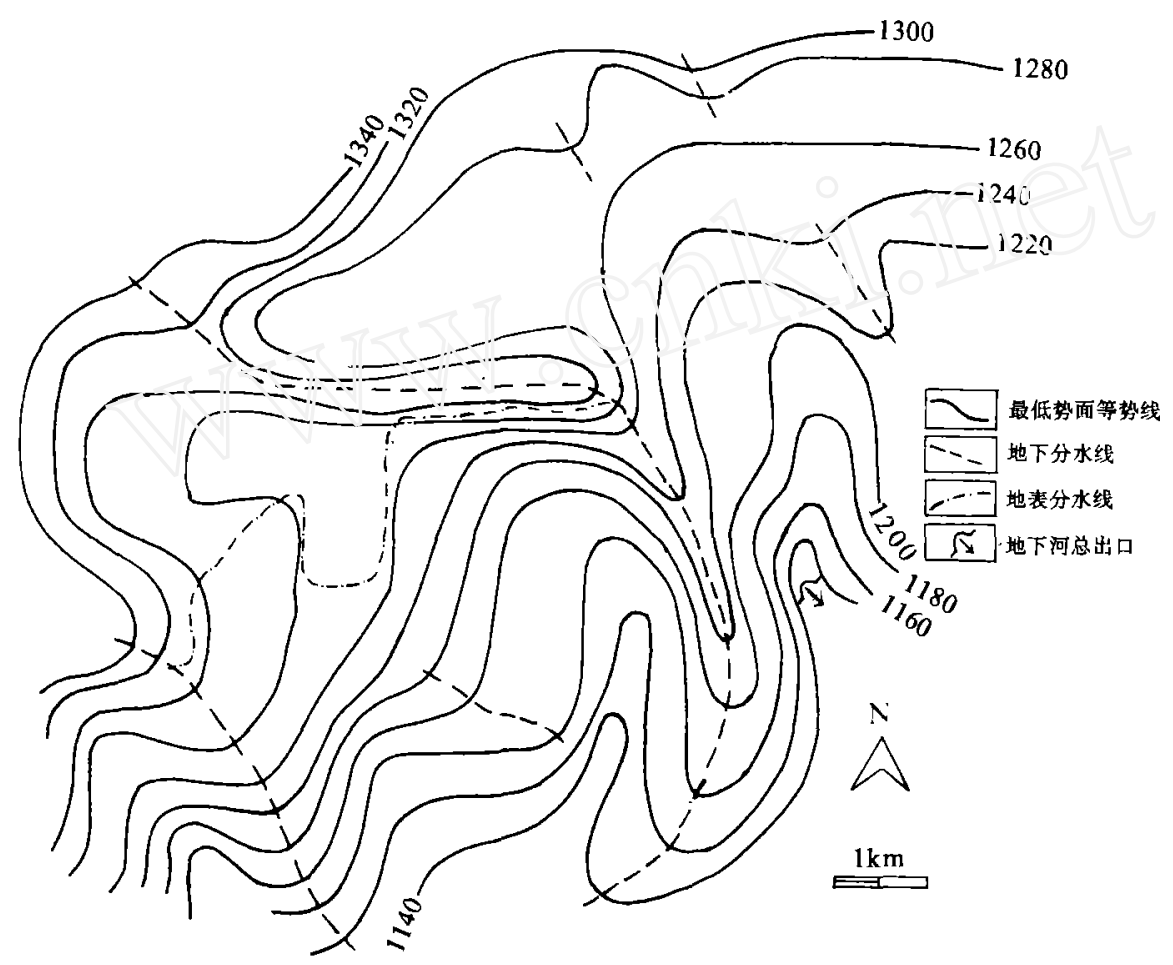

终 2 龙白地域宸似势面

Fig. 2 The mininum potential surface of Longgong region

\section{3 坡立谷湖盆的发育机制}

当喀斯特流域地貌逆向演化吋，咯斯特地块渗漏化将不断向源发展，表现为流水谷地中 出现不断后退的集中消水点。水道退化一般会导致两种结果，一种是水流沿河道两率构造裂 隙塑造出新的水流通道，并于地下不断偏离原河道，这样消水点下游方原河谷由于失去地表 线状侵蚛力面相对抬高成为干悬谷; 另一种是水流沿河道内视部裂隙下渗并在下游河道又 
集中出露,原河道中失去地表水流作用的伏流段将逐渐相对于下降的河床抬高成为分割河 道的山问垭口。在后一种模式中,流水喀斯特类型的坡立谷得以形成。以油菜河坡立谷为例 (图 3a)，该坡立谷正处在一新生垭口分割流水谷地形成封闭集水盆的发育阶段。该垭口高 $15 \mathrm{~m}$,枯水期上游水流只能于地下穿过垭口后出露于下游段，但洪水期上游水流仍可漫过垭 口从地表进入下游段。当坡立谷盆底不断降低,而垭口不断相对抬高吋,原来线状的河道便 成为完全封闭的盆状地形。如果上游河流在水系变迁过程中不断兼并扩张, 这样就极大地增 加了进入坡立谷的汇水量，而坡立谷的排水通道往往不能很快适应流域汇水增大的速度,导 致上游汇水在雨季滞蓄于坡立谷中,成为季节性喀斯特湖泊。坡立谷季节性积水使水盆周边 加速风化、溶蚛和侵蚛后退,这对湖盆横向扩大并逐激改变原来的河道线状形态而圆化有重 要的动力作用。这一阶段的坡立谷湖盆除盆底有一条狭矣的地表枯水水道外，全为漫滩所澓 盖。
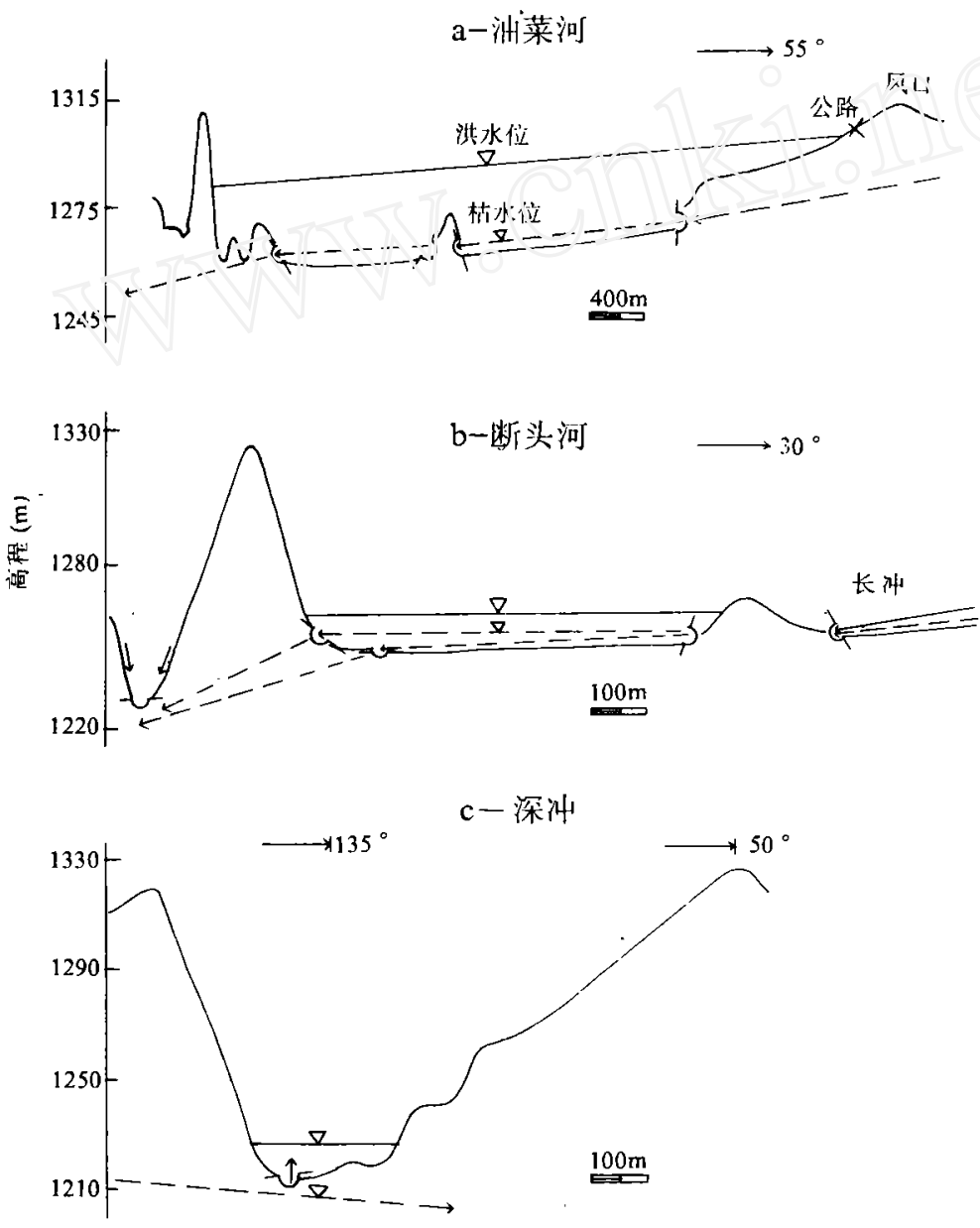

图 3 龙官地区坡立谷演化模式

Fig. 3 Evolution model of polje in Longgong region 
但进一步的漏陷化将使坡立谷湖盆向注地发展, 从而又阻止了湖盆的扩大进程。以断 头河坡立谷为例 (图 3b), 坡立谷中枯水期消水点已经后退。如果消水点最终后退到坡立谷 原出水点的上游, 这时原坡立谷完全失去常年地表水流而注地化。如深冲注地 (图 3c), 仅在 洪水期由于地下河水从注底涌出而短时积水, 这一类积水洼地湖盆已大为缩小, 坡立谷形态 已经衰亡。

实际上,上述两种过程在坡立谷的演化中通常同时存在, 如油菜河坡立谷中消水点也正 在后退, 差别仅在于不同的发育阶段这两种过程的速率对比不同。

\section{4 天然库群的调蓄功能}

安顺分水岭一带的人工水库库容小 (浅盆水库), 且离下游较远, 仅能补充仯水岭一带的 农业旱季用水, 对下游基本不具调蓄能力。但龙宫水系坡立谷湖群由于其特殊的地貌形态结 构, 使其在雨季一定吋段水流的输出小于其输入,大量的上游来水蓄积于洨、立谷中,成为季

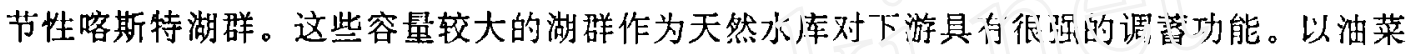

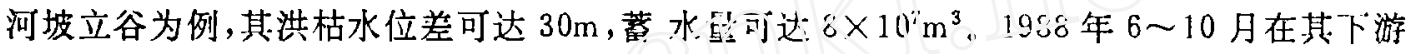

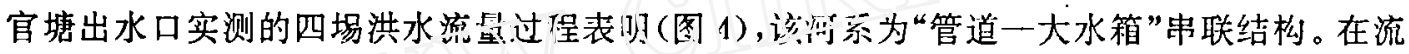

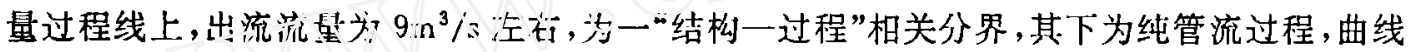

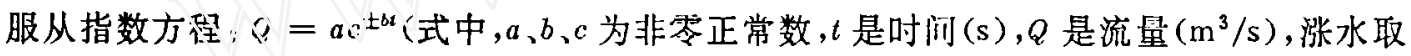
正号, 退水取为负号); 其上为迭加了坡立谷大水箱的库流过程, 曲线服从线性方程 $Q=Q_{0} \pm k t$ (式中, $Q$ 是流量, $Q_{0}$ 是初始流量, $k$ 是非苓正常数, $t$ 是时问, 涨水取正号, 退水取 负号)。经计算, 从 8 月到 10 月两埸洪水的末调葙涨水段为 $Q=Q_{0} \mathrm{e}^{0.011 t}$, 调节后为 $Q=Q_{0}+$ $0.037 \mathrm{t}$; 未调节退水段为 $Q=Q_{0} \mathrm{e}^{-0.008 \mathrm{t}}$, 经过调少为 $Q=Q_{0}-0.0176 \iota_{\text {。 }}$ 很吗显, 库流的洮水 曲线和退水曲线均比相应的管流曲线平缓, 从而延长了出流过程, 即将洪水过程线的底宽拉 长。

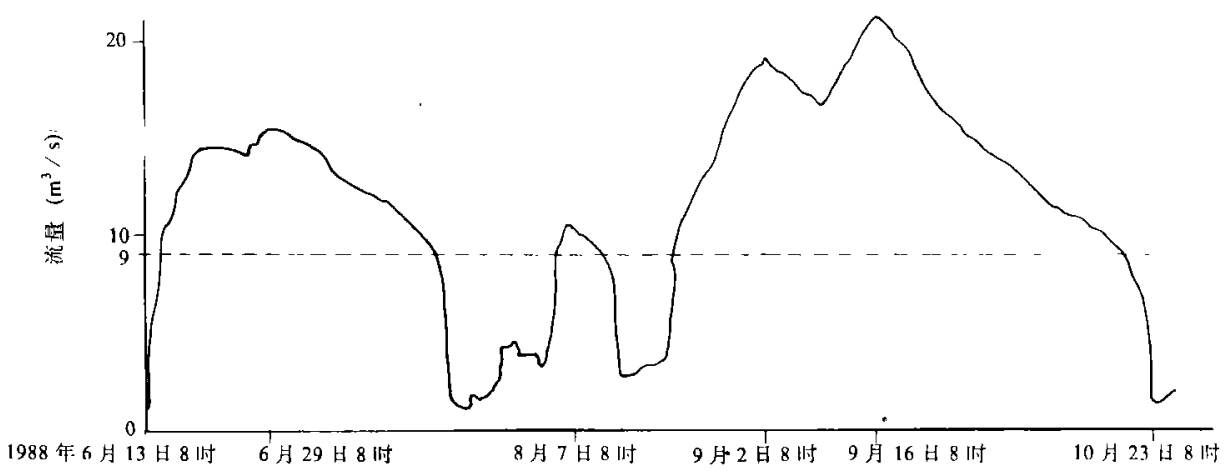

图 4 油菜河坡立谷出淤流量过程

Fig. 4 Graph of outflow of Youcaihe Polje 
目前, 为了充少开发利用龙宫地区的喀斯特风景资源, 有关部门正组织人力在油菜河坡 立谷西端出水口筑坝建闸, 以使这个天然水库对下游湖群和龙宫洞水位具有更强的可控调 节作用。

\section{5 结 语}

世界上最大的坡立谷溶盆是南斯拉夫的 Popov 溶盆, 建库前的天然容量达 $9.8 \times$ $10^{8} \mathrm{~m}^{3}$, 是油茶河坡立谷的 10 倍。此外，在南斯拉夫容量为 $10^{8} \mathrm{~m}^{3}$ 级的溶盆还有 5 个,但它们 多与构造断陷有关。同样,在中国喀斯特区,较大的盆地如贵州的水城盆地 (曾经积水)、草海 (正在积水)也均与断陷有关。而主要为水文地貌成因的喀斯特湖盆如贵州安龙坡立谷湖 盆 ${ }^{[4]}$ 以及龙宫坡立谷湖盆, 其规模一般不大,这是由于湖盆的积水扩张过程被溯源而上的洼 地化过程所中断。但这一类湖盆的发育喀斯特作用和流水作用占了主导地位。其积水机制 主要为阻塞和河流作用。因此，“喀斯特湖”这一概念的内酒治有街于湖淊学者暑理范定。

致谢 全文承塚林承坤整投审阅并提出宝贵意贸; 对外工作得到贵州省水文总站的协 助, 在此一并琣说。

\section{参 考 文 献}

1 Gams I. The polje, the problem of its definition. Z Geumorph, 1978,22:170 181

2 Gams I. The terminology of the types of poljc. Slovenska Krasa T erminologija, Zveza Gcografskih Inst itucij Jugoslavije, Ljubljana, 1972; 60 67

3 㯰 明. 贵州嗦斯特水文地貌模型及其应用初步研究. 地理学报, 1991,48(4):460 469

4 证明. 安龙地区海子(坡立谷)水文地貌成因分析.川国岩溶, 1992,11(2):149 154

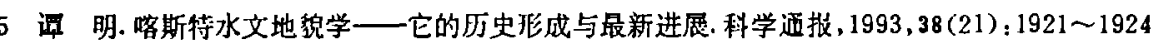

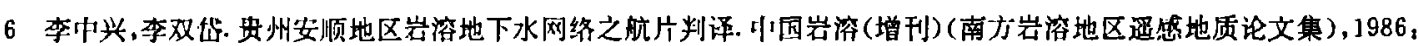
$99 \sim 112$

7 Schumm S A. Gcomorphic thresholds and complex response of drainage systems. In: Morisawa $M$ ed. Flurial Geomorphology, Publications in Gcomorphology, Sate Univ., Ncw York, Binghamton, 1973. 299 310 


\title{
HYDROGEOMORPHOLOGIC STRUCTURE AND FUNCTION OF KARST LAKES IN LONGGONG REGION, GUIZHOU
}

\author{
$\mathrm{T}$ an $\mathrm{M}$ ing \\ (Department of Geo and Ocean Science, Nanjüg University, Nanjüg 210093) \\ Liang Hong \\ (Department of Geography, Guizhou Normal Uninersity, Guunang 550001)
}

\begin{abstract}
Longgong is a famous scenic spot in the karst region of Guizhou Province. The landscape and rivers were rejuvenated in Longgong region by the tectonis movament in Quaternary Period, which arranged series of morphology in the carcliment that consisted of fluvial valleys, blind valleys, poljes and deprescionsi in turn fiom the wivide to the base. Such poljes are dominated by two processe:; - -... ilie fuviai one from upper course which keeps the poljes possessing the forr of ite valley, and the karst one from downstream which made the poljes change into depressions or seasonal lakes because their drainage systems are still not fitted to the modification of the catchment. In the case the poljes perform a natural function of hydrologic adjustment.
\end{abstract}

Key Words Longgong River System, polje, karst lake, complex response, hydrogeomorphology 